\title{
INFLUENCE OF SYSTEMIC INFLAMMATORY RESPONSE ON IN HOSPITAL OUTCOME IN PATIENTS WITH TYPE 2 DIABETES MELLITUS AND ST-SEGMENT ELEVATION MYOCARDIAL INFARCTION UNDERGOING PRIMARY PERCUTANEOUS CORONARY INTERVENTION
}

\author{
Veljko Milić, Boris Džudović, Slobodan Obradović \\ Military Medical Academy Belgrade, Clinic for Emergensy and Internal Medicine, Belgrade, Serbia \\ Contact: Veljko Milić \\ Military Medical Academy \\ Crnotravska 17, 11000 Belgrade, Serbia \\ E-mail:veljkomdr@gmail.com
}

Subjects with type 2 diabetes mellitus (T2DM) constitute $13-25 \%$ of patients with acute myocardial infarction with ST-segment elevation (STEMI) hospitalized for myocardial reperfusion therapy. The aim of this study was to evaluate systemic inflammatory respo-nse in patients with T2DM and STEMI undergoing primary angioplasty at our clinic and to estimate prognostic significance of inflammatory markers, C-reactive protein (CRP), for inhospital mortality in type 2 diabetics compared to those without diabetes.

The retrospective-prospective clinical study included 574 STEMI patients (122 with, and 452 without T2DM), both male and female, who underwent primary percutaneous coronary intervention ( $\mathrm{PPCI}$ ). Examination of the biochemical parameters demonstrated significantly higher concentrations of CRP [med CRP mg/L (25th-75th) 45.0 (12.0 to 101.0) to 25.8 (from 11.3 to 53.7$), p=0.013]$ and glucose levels $(12.4 \pm 5.9$ vs. $7.8 \pm 1.9, p=0.001)$ in subjects with diabetes. There were no differences between the groups rega-rding the activity of CK$M B$ fraction and LDH.

Multivariate analysis showed that CRP is an independent prognostic factor of adverse outcome in the first 30 days after primary PCI in non-diabetic group, followed by patient age and smoking $(95 \% \mathrm{CI})[1.012(1.004-1.020) ; p=0,004]$. In contrast to diabetic patients, $a$ significant mortality in non-diabetics was observed for the third tertile of $(95 \% \mathrm{CI})[1.014$ $(1.008-1.020) ; p=0.001]$. This findings were presented on the Caplan-Mayer curve.

C-reactive protein turned out to be an independent prognostic factor for hospital mortality for the patients without diabetes mellitus type 2 undergoing primary percuta-neous coronary intervention. Acta Medica Medianae 2017;56(2):5-12

Key words: STEMI, C-reactive protein, primary percutaneous coronary intervention, type 2 diabetes mellitus, inflammation 